\title{
Robert Marek
}

Akademia Morska w Gdyni

e-mail: r.marek@wpit.am.gdynia.pl

\section{ROZWÓJ KRAJOWEGO PORT COMMUNITY SYSTEM DEVELOPMENT OF THE POLISH PORT COMMUNITY SYSTEM}

DOI: $10.15611 / \mathrm{pn} .2018 .505 .28$

Streszczenie: Polski port community system (PCS) powinien połączyć wszystkie polskie porty morskie z podmiotami, które odgrywają istotną rolę w podniesieniu konkurencyjności portów morskich. Chociaż system ten ma na celu przyniesienie korzyści jego użytkownikom, to mimo to wielu przedsiębiorców nie dysponuje wiedzą na temat istoty i znaczenia tego systemu. W związku z tym autor artykułu przeprowadził analizy: (a) form prawno-organizacyjnych operatorów PCS; (b) możliwości integracji port community system z single window; (c) zakresu danych, informacji i dokumentów będących przedmiotem transferu w istniejących PCS w Unii Europejskiej. Uzyskanie wyniki analizy mogą stanowić przyczynek do odpowiedzi na pytanie: co w istocie rzeczy decyduje o modelu polskiego port community system?

Słowa kluczowe: port community system, single window.

Summary: Polish port community system (PCS) has to link up all Polish seaports with all the companies that play a crucial role for the competitive power of the port. Although this system has promising benefits for the users, a lot of entrepreneurs do not have knowledge on the essence and meaning of the system. Therefore, the author of paper ran a study on: (a) business model of PCS' operators; (b) possibilities of PCS and SW integration; (c) scope of data, information and documents provided by PCS (existing in UE seaports) to its users. The results of the study can be used in the answer on the following question: How shall the Polish port community system be created in the close future?

Keywords: port community system, single window.

\section{Wstęp}

\section{Pojęcie port community system}

Istnieje wiele sposobów definiowania określeń i zagadnień związanych z port community system. Złożoność problemów dotyczących stworzenia, wdrożenia i utrzymania port community wskazuje na trudność powstania jednoznacznej i zwartej definicji. 
Od wielu lat problem port community system nabiera coraz większego znaczenia dla przedsiębiorstw skoncentrowanych $\mathrm{w}$ obrębie obrotu portowo-morskiego. W rezultacie coraz więcej ośrodków akademickich, organizacji biznesowych, politycznych, pozarządowych stara się rozpoznać istotę port community system oraz usiłuje ją doprecyzować. Przegląd definicji port community system przedstawia tabela 1.

Tabela 1. Przegląd definicji port community system

\begin{tabular}{|c|c|}
\hline Autor & Definicja \\
\hline $\begin{array}{l}\text { J. Rodon i J. Ramis-Pujol } \\
\text { [2006] }\end{array}$ & $\begin{array}{l}\text { „Elektroniczna platforma, która łączy wiele systemów } \\
\text { informacyjnych, użytkowanych przez liczne organizacje, które } \\
\text { tworzą społeczność portu morskiego”. }\end{array}$ \\
\hline PORTEL [PORTEL] & $\begin{array}{l}\text { „Platforma współpracy, która ułatwia elektroniczną wymianę } \\
\text { informacji, dotyczących handlu i spraw administracyjnych, tworząc } \\
\text { relację B2B w otoczeniu portu”. }\end{array}$ \\
\hline $\begin{array}{l}\text { European Port Community } \\
\text { System Association (EPCSA) } \\
\text { [EPCSA] }\end{array}$ & $\begin{array}{l}\text { „Neutralna i otwarta platforma umożliwiająca inteligentną } \\
\text { i bezpieczną wymianę informacji pomiędzy publicznymi } \\
\text { i prywatnymi interesariuszami w celu podniesienia efektywności } \\
\text { i umocnienia pozycji konkurencyjnej portów morskich } \\
\text { i lotniczych”. }\end{array}$ \\
\hline Capgemini [www1] & $\begin{array}{l}\text { „Jednostka dostarczająca informacji dla uczestników łańcucha } \\
\text { podaży przechodzącego przez porty morskie. Port community } \\
\text { system jest odpowiedzialny za: dostarczenie danych, kontrolę } \\
\text { danych, dystrybucje danych i konwersję danych”. }\end{array}$ \\
\hline PORTEL9 [9SKEMA 2007] & „Narzędzie wymiany wiadomości w otoczeniu przedsiębiorstwa”. \\
\hline P. Grizell [2001] & $\begin{array}{l}\text { „Centralny system operacyjny, umożliwiający transfer danych } \\
\text { i oferujący realizację różnych usług operacyjnych na tych danych, } \\
\text { które mogą być wykorzystane przez każdą stronę, która jest } \\
\text { zainteresowana handlem morskim. Port community system unika } \\
\text { bilateralnego transferu danych”. }\end{array}$ \\
\hline
\end{tabular}

Źródło: opracowanie własne.

Z przytoczonych definicji wynika, że port community system ma zapewnić: (a) uporządkowaną komunikację między interesariuszami systemu (tj. przedsiębiorstwami prywatnymi oraz instytucjami sfery publicznej uczestniczącymi w łańcuchach logistycznych przechodzących przez porty morskie - zob. rys. 1 i 2); (b) zintegrowanie, zsynchronizowanie i zharmonizowanie danych, informacji i obieg dokumentów w systemie; (c) bezpieczeństwo oraz ochronę danych i informacji przechodzących przez system; (d) wzrost wartości dodanej dla uczestników systemu (m.in. poprzez szybszy dostęp uczestników systemu do danych i informacji, co powinno usprawnić i podnieść efektywność przepływu ładunków między podmiotami); (e) neutralność uczestnikom korzystającym z systemu; (f) transfer danych i informacji zgodnie z prawem i normami etycznymi przyjętymi przez społeczność logistyki morskiej ${ }^{1}$.

\footnotetext{
${ }^{1}$ Szerzej na temat logistyki morskiej zob. [Ficoń 2013; Marek 2013, s. 35-54].
} 


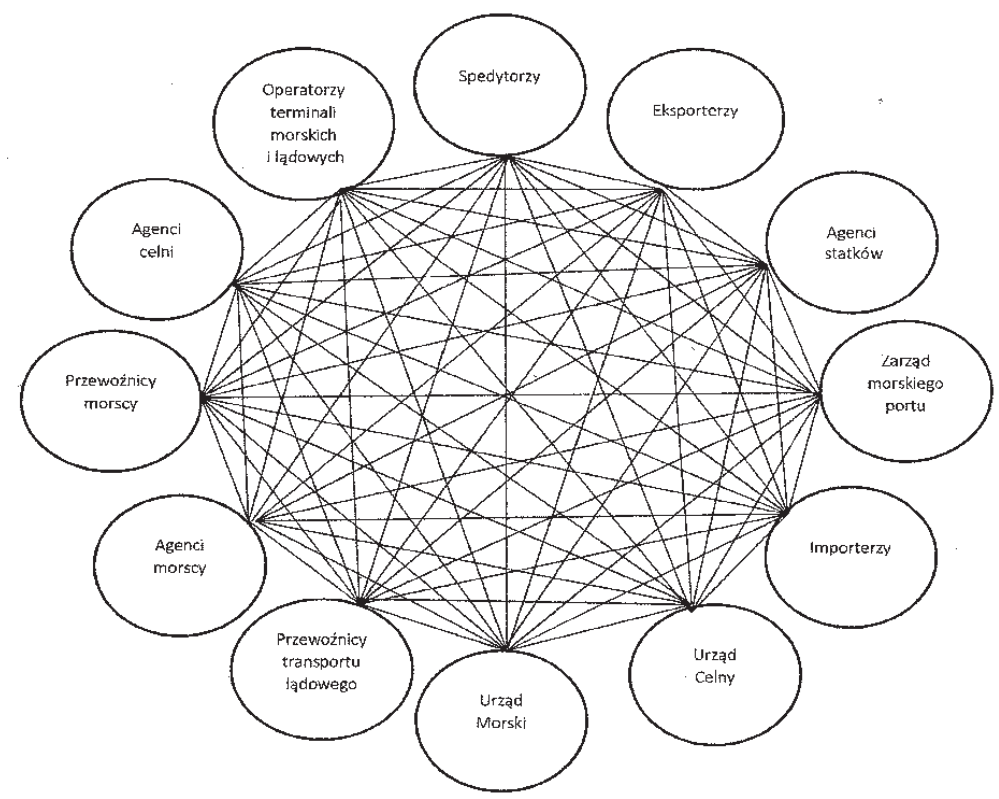

Rys. 1. Tradycyjny model komunikacji w porcie morskim

Źródło: opracowanie własne.

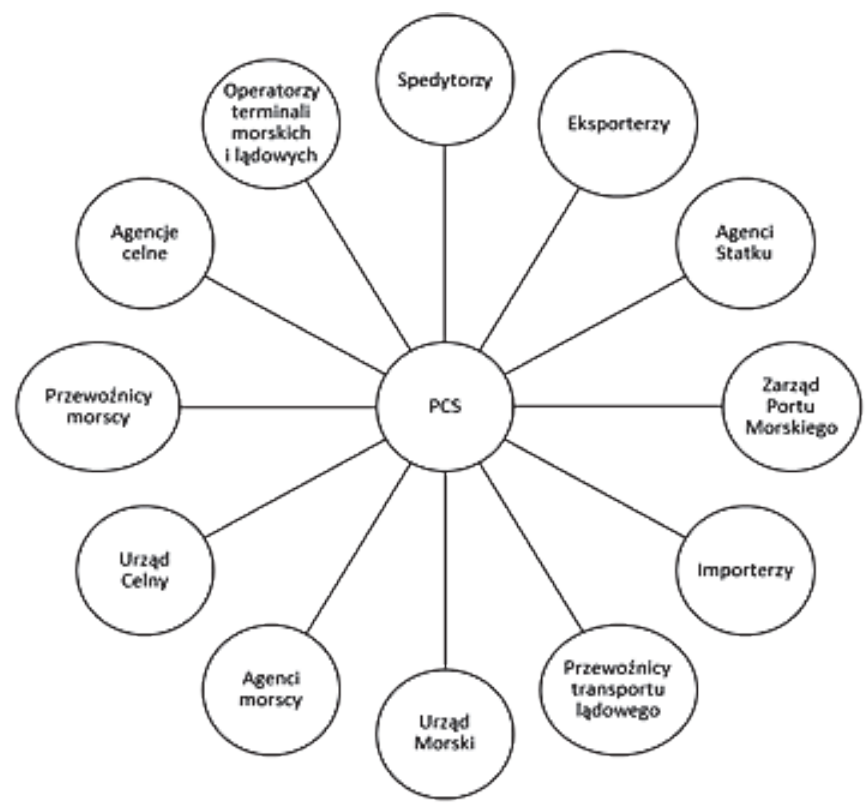

Rys. 2. Model komunikacji w portach morskich przy wykorzystaniu port community system Źródło: opracowanie własne. 
Należy zwrócić uwagę, że stworzony port community system nie może spowodować zmian w obecnej sile i strukturze przedsiębiorstw działających na rynku, innymi słowy PCS nie może przyczynić się do umocnienia pozycji konkurencyjnej jednej grup podmiotów kosztem innej grupy przedsiębiorstw. Istnieje np. bardzo silna konkurencja między armatorami żeglugi kontenerowej, którzy rozszerzają ofertę swoich usług o zadania realizowane dawniej przez spedytorów morskich. Zatem port community system powinien być tak stworzony, aby poprzez transfer danych, informacji i dokumentów nikt nie zyskał kosztem innych.

Analizując rysunki 1 i 2, można jednoznacznie wykazać, że port community system porządkuje przepływ danych, informacji i obieg dokumentów między licznymi uczestnikami systemu.

\section{Formy prawno-organizacyjne funkcjonowania port community system}

Tworzenie port community system nierozerwalnie łączy się z określeniem formy prawno-organizacyjnej operatora. Wybór formy operatora port community system stanowi, z jednej strony, efekt uwarunkowań i dobrych praktyk rynkowych, w ramach których przyszły operator systemu ma funkcjonować, z drugiej zaś - efekt koncepcji przyjętej i nakreślonej przez inicjatorów-właścicieli. Niewątpliwie forma prawno-organizacyjna operatora port community system związana jest bezpośrednio z typem lokalnych organizacji (interesariuszy) wspierających rozwój tego systemu.

Mając na uwadze kryterium własności, można wyróżnić następujące formy prawno-organizacyjne operatora port community system [Keceli 2011, s. 151-167]:

- prywatne,

- państwowe,

- mieszane.

Pierwsza forma prawno-organizacyjna polega na utworzeniu przedsiębiorstwa prywatnego - operatora systemu, który jest odpowiedzialny za jego stworzenie, wdrożenie oraz utrzymanie. Najczęściej operator PCS jest zorganizowany w formie spółki kapitałowej. W tym przypadku port community system tworzony jest jako inicjatywa oddolna, aczkolwiek mająca szerokie poparcie głównych interesariuszy tego systemu, tj. zarządu portu morskiego, operatorów terminali morskich i lądowych, przedsiębiorstw żeglugi morskiej, urzędu celnego, urzędu morskiego oraz innych istotnych graczy działających w środowisku portowo-morskim. W niektórych portach morskich rozwój port community system wspierany jest również przez prywatne stowarzyszenia przedsiębiorców (np. izby handlowe) oraz instytucje finansowe (m.in. banki komercyjne, towarzystwa ubezpieczeniowe). W Polsce tego typu inicjatywa została podjęta przez spółkę HTPCS (High Technology Port Community System) Sp. z o.o., która została zawiązana jako podmiot celowy ukierunkowany na stworzenie polskiego port community system, obejmującego swoim zasięgiem porty morskie: Gdyni, Gdańska i zespół portów morskich Szczecina-Świnoujścia (zob. rys. 3). 


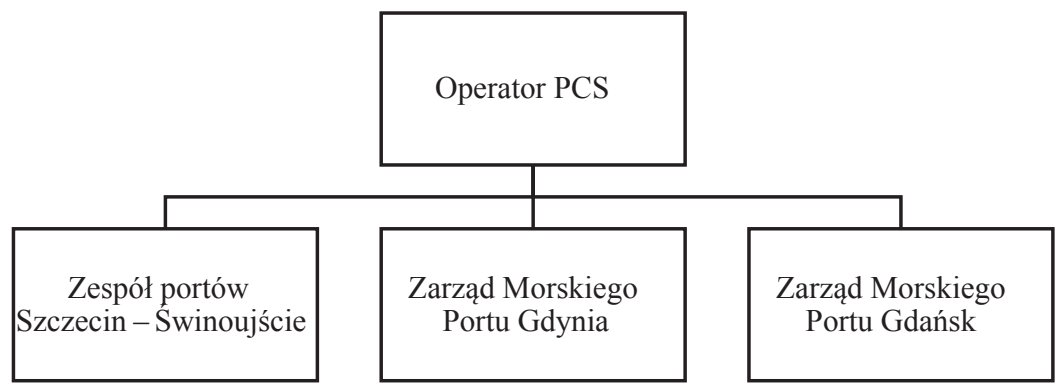

Rys. 3. Proponowana struktura polskiego port community system

Źródło: opracowanie własne.

Stworzenie port community system przez podmiot państwowy stanowi inicjatywę odgórną podejmowaną przez właściwy organ państwowy - ministerstwo branżowe lub zarząd portu morskiego. Zarząd portu morskiego lub powołane celowe przedsiębiorstwo państwowe pełni rolę operatora systemu. Przedsiębiorstwo państwowe tworzy, wdraża i utrzymuje port community system. W przypadku kiedy operatorem PCS jest państwowa spółka celowa, to część udziałów (akcji) może zostać sprzedana użytkownikom systemu, ale w taki sposób, aby nie zakłócić obowiązującego porządku biznesowego. Tego typu rozwiązanie ma miejsce w krajach, w których istnieje silna presja władz państwowych na aktywne uczestniczenie w życiu gospodarczym.

Inną formą prawno-organizacyjną operatora port community system spotykaną na rynku europejskim jest partnerstwo publiczno-prywatne. Tego typu rozwiązanie może mieć charakter inicjatywy odgórnej, jak i oddolnej. W przypadku wyboru tej formy podmiot prywatny najczęściej odpowiedzialny jest za stworzenie, wdrożenie i utrzymanie systemu, a następnie zgodnie z warunkami umowy przekazuje PCS na

Tabela 2. Formy prawno-organizacyjne port community system w wybranych krajach UE

\begin{tabular}{|l|l|l|l|l|l|l|}
\hline \multicolumn{1}{|c|}{ Kraj } & Port & $\begin{array}{c}\text { Nazwa } \\
\text { PCS }\end{array}$ & $\begin{array}{c}\text { Typ } \\
\text { systemu }\end{array}$ & $\begin{array}{c}\text { Nazwa lokalnego } \\
\text { przedsiębiorstwa } \\
\text { zarządzającego } \\
\text { PCS }\end{array}$ & $\begin{array}{c}\text { Forma prawno- } \\
\text {-organizacyjna } \\
\text { PCS }\end{array}$ & $\begin{array}{c}\text { Model } \\
\text { biznesowy }\end{array}$ \\
\hline Francja & Le Havre & AP + & PCS + SW & SOGET SA & Mieszana & PPP \\
\hline Niemcy & Hamburg & Dacosy & PCS + SW & Dacosy & Prywatna & Z dołu do góry \\
\hline Belgia & Antwerp & Porthus.net & PCS + SW & Port-I-Com & Mieszana & PPP \\
\hline Holandia & Rotterdam & Portbase & PCS + SW & Portbase & Publiczna & Z góry na dół \\
\hline Włochy & Livorno & TPCS & PCS + SW & Port authority & Publiczna & Z góry na dół \\
\hline Włochy & Venice & LOGis & PCS & Port authority & Publiczna & PPP \\
\hline Włochy & Genoa & E-Port & PCS + SW & Port authority & Publiczna & PPP \\
\hline
\end{tabular}

Źródło: opracowanie własne na podstawie [University of Naples 2011, s. 20]. 
rzecz sektora państwowego lub przekazuje część swoich udziałów w spółce celowej ${ }^{2}$. Należy jednak zaznaczyć, że w tym przypadku istnieją różne rozwiązania hybrydowe dotyczące etapu (stworzenia, wdrożenia, utrzymania systemu), za jaki odpowiedzialny jest podmiot prywatny. Dobrym przykładem funkcjonowania operatora port community system na zasadach partnerstwa publiczno-prywatnego jest system SOGET (Francja) [www2]. Przykładowe formy prawno-organizacyjne operatorów port community system zaprezentowano w tabeli 2.

Niewątpliwie forma prawno-organizacyjna operatora PCS zaakceptowana w chwili tworzenia może ulec zmianie w zależności od upływu czasu i zgromadzenia określonych doświadczeń, związanych z rozwojem bądź brakiem rozwoju systemu.

\section{Powiązania port community system $\mathrm{z}$ single window}

Port community system jest tworzony jako platforma elektronicznej wymiany danych, informacji i dokumentów między jego użytkownikami, uwzględniająca ich uwarunkowania ekonomiczne i prawne. PCS pełni rolę integratora otwartej liczby podmiotów - użytkowników prywatnych. Jednak aby system funkcjonował w sposób poprawny, operator musi sprawdzić każde przedsiębiorstwo, które przystąpi do systemu, czy posiada odpowiedni poziom sprawności informatycznej oraz czy zainteresowane jest współpracą z pozostałymi przedsiębiorstwami działającymi w obrocie portowo-morskim za pomocą systemu. Port community system musi być powiązany systemowo z państwowym single window (SW). Aspekt integracji obu systemów jest szczególnie uwypuklony w definicji EPCSA, która stanowi, że „PCS jest neutralną i otwartą platformą elektroniczną umożliwiającą inteligentny i bezpieczny przepływ informacji pomiędzy publicznymi i prywatnymi interesariuszami w celu poprawienia pozycji konkurencyjnej portów morskich i lotniczych. [...] optymalizuje, zarządza i automatyzuje efektywnie procesy przechodzące przez porty morskie i lotnicze za pomocą jednorazowego wprowadzenia danych do systemu i łączy łańcuchy transportowe i logistyczne" [EPCSA]. Ponadto PCS zapewniający elektroniczną wymianę danych, informacji i dokumentów między wszystkimi portami i sektorami logistyki jest uznawany za najbardziej zaawansowany, i w takim kierunku powinno zmierzać stworzenie polskiego port community system. Dzięki stworzeniu krajowego morskiego single window będzie możliwe zredukowanie powielania tych samych danych, informacji i dokumentów oraz użytkowania tylko jednego systemu³.

${ }^{2}$ W Polsce Instytut Logistyki i Magazynowania w Poznaniu podjął się również stworzenia krajowego PCS, aczkolwiek nie ma jeszcze wypracowanej formy prawno-organizacyjnej operatora systemu. Władze ILIM w Poznaniu postulują formę operatora zorganizowaną na zasadach partnerstwa publiczno-prywatnego lub państwowego. Jednak wybór formy prawno-organizacyjnej operatora PCS jest obecnie przedmiotem dyskusji i analiz.

${ }^{3}$ Obecnie spedytor morski musi znać i obsługiwać wszystkie terminalowe systemy operacyjne oferowane przez operatorów takich jak: DCT, BCT, GTC, OT Logistic Terminal itp. Dzięki istnieniu 
Dobrym przykładem obrazującym korzyści osiągane przez użytkowników PCS działających w innych portach morskich jest manifest ładunkowy. Manifest ładunkowy przekazywany jest urzędowi celnemu dla celów operacyjnych i kontroli fiskalnej. Obecnie prawie $100 \%$ manifestów ładunkowych jest transferowanych elektronicznie do PCS, głównie przy wykorzystaniu wiadomości UN/UDIFACT CUSCAR, zastępując tym samym siedem kopii, które dotychczas były przedmiotem cyrkulacji między podmiotami obrotu portowo-morskiego. Oczywiście istnieje niewielka liczba przedsiębiorstw, które nie mają zdolności informatycznej do przesyłania danych elektronicznie. Dane znajdujące się w manifeście ładunkowym przechodzącym przez PCS umożliwiają realizacje innych wymagań regulacyjnych ciążących na zarządach portów morskich oraz przewoźnikach, jednocześnie umożliwiając tym ostatnim wprowadzenie danych tylko jeden raz do systemu [www3]. W rezultacie raz wprowadzone dane do centralnej bazy danych są dostępne uczestnikom systemu w zależności od posiadanego poziomu uprawnienia.

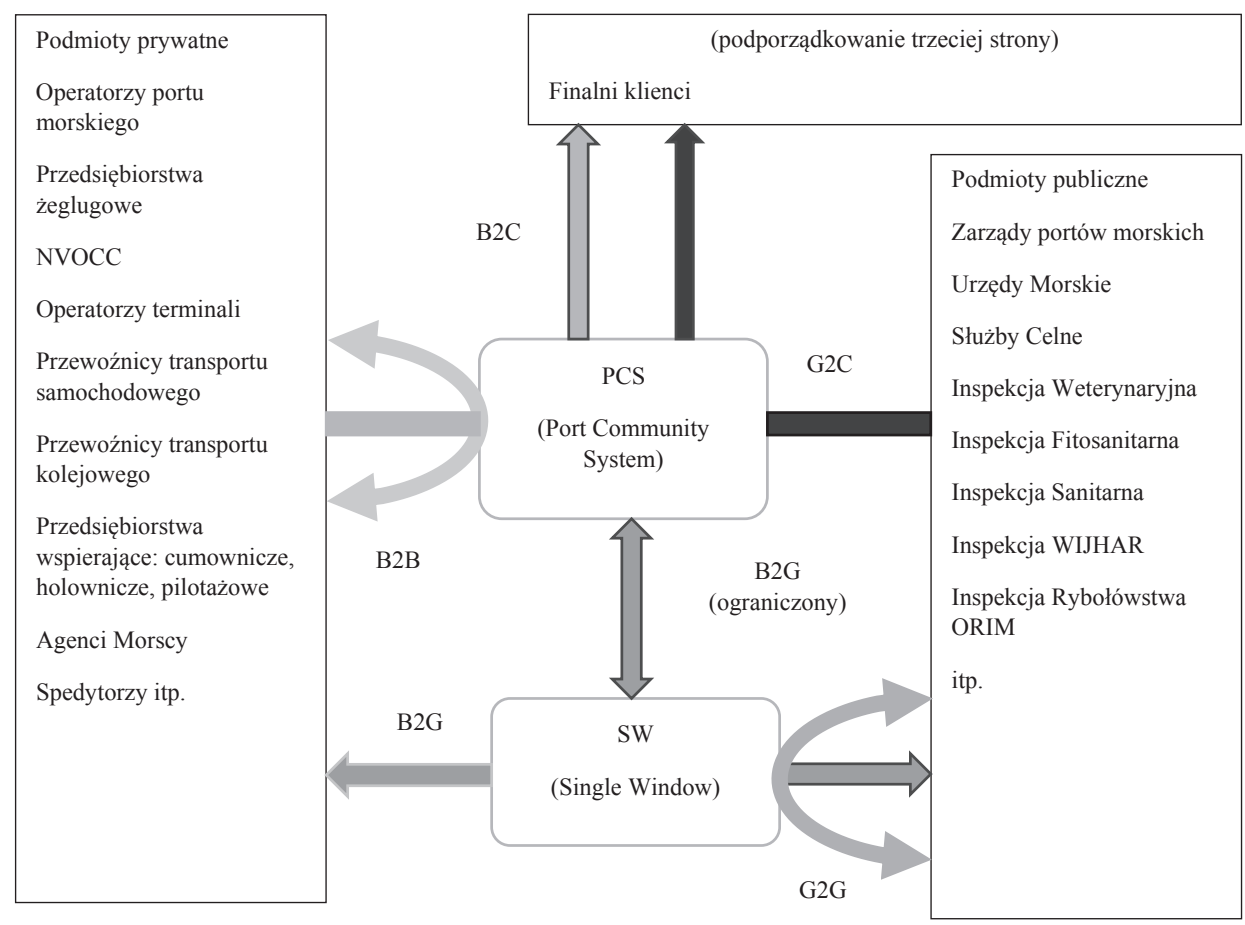

Rys. 4. Częściowo zintegrowany PCS z SW

Źródło: opracowanie własne zmodyfikowane na podstawie [University of Naples 2011, s. 14].

krajowego PCS spedytor będzie musiał znać tylko obsługę tego systemu. Krajowy port community system powinien automatycznie przekazywać dane, informacje i dokumenty do zdefiniowanego przez spedytora terminalu poprzez wpisanie jego indywidualnego kodu. 
Wszystkie te elementy wskazują na określenie ścisłych relacji występujących pomiędzy port community system a single window. Obecnie wyodrębnia się dwa podejścia mające na celu integracje tych dwóch systemów, zob. rys. 4 i 5.

W pierwszym przypadku PCS i SW działają jako dwa oddzielne systemy, przy czym PCS głównie odnosi się do transakcji realizowanych w relacji Business-to-Business (B2B) oraz Business-to-Customer (B2C). Z kolei w przypadku SW mamy jednokierunkowy przepływ danych, informacji i dokumentów w relacji Business-to-Government (B2G) oraz wielokierunkowy w relacji Goverment-to-Government (G2G). Single window stworzone jest z myślą głównie o przepływie danych między instytucjami państwowymi. Niewątpliwie poprzez tego typu współdziałanie dwóch odrębnych systemów osiągane są korzyści w postaci oszczędności czasu (np. brak powielania danych, informacji oraz dokumentów przez różnych uczestników, możliwość podjęcia szybszej decyzji przez organ publiczny, integracja niektórych instytucji publicznych w ramach jednego wspólnego systemu - Port-24 itp.). Jednak to rozwiązanie nie jest w pełni zadowalające, gdyż prywatni operatorzy systemu mają dwa punkty dostępu wprowadzania danych: dla podmiotów prywatnych i publicznych.

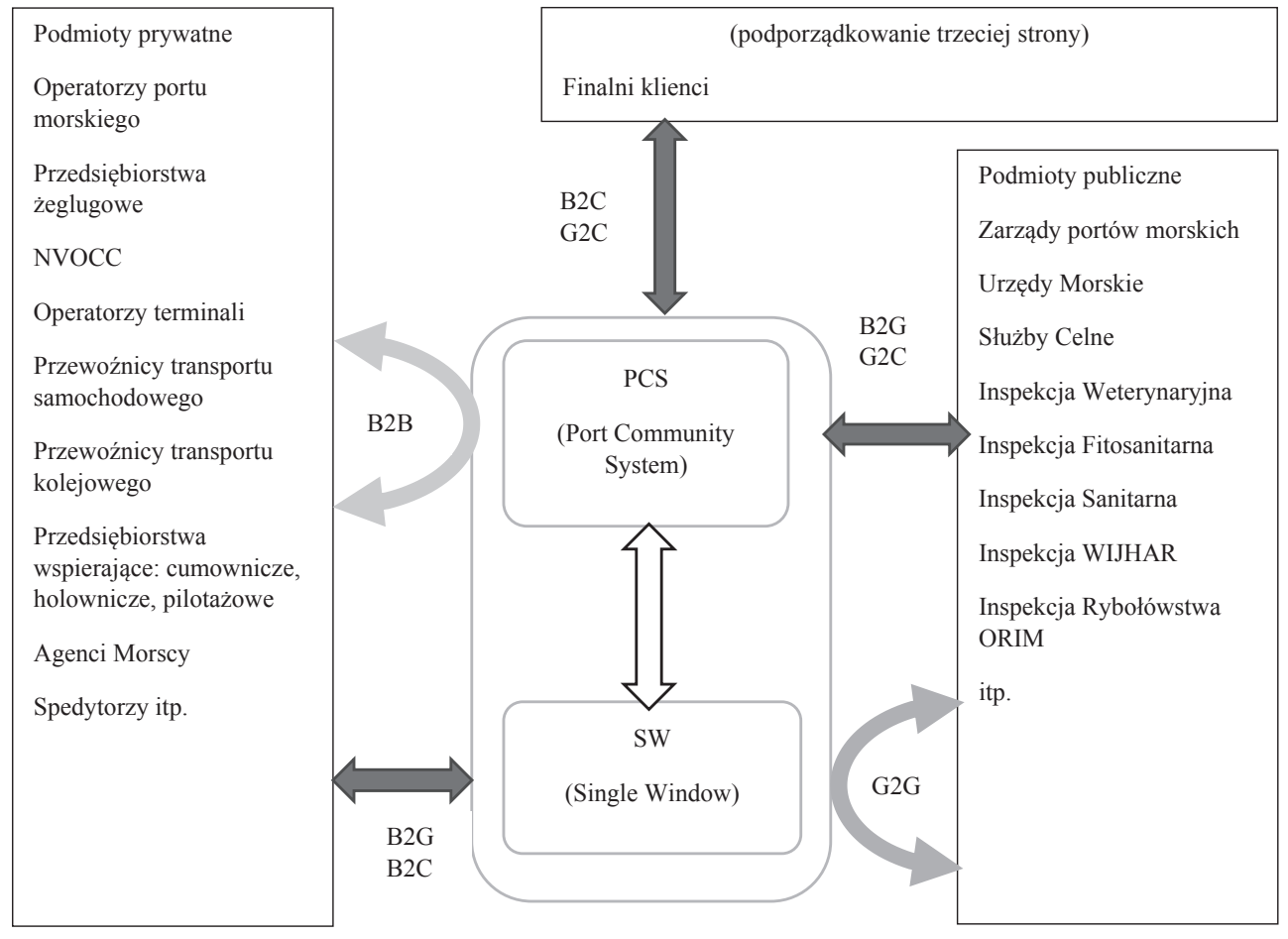

Rys. 5. Pełne zintegrowanie PCS i SW

Źródło: opracowanie własne zmodyfikowane na podstawie [University of Naples 2011, s. 14]. 
W drugim przypadku istnieje interfejs między PCS a SW zapewniający całkowitą integrację pomiędzy tymi systemami. To rozwiązanie jest bardziej przyjazne użytkownikom PCS, ponieważ istnieje tylko jeden punkt dostępu wprowadzania danych do systemu. Ponadto, w przypadku pełnej integracji obu systemów, PCS musi spełniać wszystkie wymagania bezpieczeństwa transferu danych określone przez właściwy organ państwowy.

Niewątpliwie istnieje wiele wariantów rozwiązań integrujących port community system $\mathrm{z}$ single window. Jednak budując system w polskiej przestrzeni portowo-morskiej, należy uwzględnić wewnętrzne uwarunkowania istniejącej architektury systemu IT w porcie morskim. Praktyczny rozwój takiego czy innego rozwiązania integrującego port community system z single window zależy od woli lokalnych organizacji, które inicjują jego stworzenie, wdrożenie i utrzymanie.

\section{Zakres danych i informacji przechodzących przez port community system}

Zakres przetwarzanych danych, informacji i dokumentów w port community system jest zróżnicowany w zależności od potrzeb interesariuszy (użytkowników) oraz etapu rozwoju systemu. PORTEL [PORTEL] przeprowadził badania mające na celu zidentyfikowanie zakresu danych i informacji wykorzystywanych przez użytkowników port community system działających w UE. Wyniki przeprowadzonych badań umożliwiły dokonanie podziału danych i informacji na grupy [University of Naples 2011, s. 16]:

- oferujące usprawnienie kontroli ładunków na terminalu kontenerowym (np. kontrola wejścia/wyjścia kontenera przez bramę terminalu itp.);

- usprawniające zarządzanie wpłynięciem/wypłynięciem statku do/z portu morskiego (tj. harmonogramy rozkładów statków, powiadomienia o wejściu lub wyjściu statku do/z portu morskiego itp.);

- operacyjne, dotyczące lokalizacji i parametrów technicznych nabrzeża, instrukcji żeglugowych, statusu ładunku (załadowany/wyładowany), deklaracji celnych, manifestów ładunkowych, ładunków niebezpiecznych, deklaracji ładunkowych, listy ładunków załadowanych/wyładowanych, listy transshipmentów, informacji o podstawowych usługach (w zależności od statusu kontenera) oraz statystyk portowych.

Niektóre port community system oferują swoim użytkownikom dane i informacje dotyczące: wcześniejszego powiadomienia o przybyciu samochodu/wagonu/składu kolejowego, tworzenia harmonogramów floty samochodowej i kontroli systemu (np. system Potic - port Barcelona umożliwia tworzenia raportów do magazynów klienta), planu sztauowania ładunku w kontenerze (m.in. oferowany jest przez Dakosy - port Hamburg; zob. tab. 3), przesyłu raportów uszkodzenia/naprawy kontenera, integracji z krajową lub międzynarodową elektroniczną platformą, wystawiania rachunków/ faktur. 
Większość port community system działających w UE koncentruje się na procesie przepływu kontenerów - w imporcie - to jest z obszaru morskiego do zaplecza portu morskiego, oraz monitoringu ładunków niebezpiecznych [University of Naples 2011, s. 15]. Tylko nieliczne port community system działające w UE oferują swoim użytkownikom dostęp do danych i informacji na temat ładunków masowych, natomiast w żadnym systemie nie są ujęte ładunki ro-pax [University of Naples 2011, s. 15].

Tabela 3. Taksonomia transakcji, interesariusze i platformy PCS Hamburg

\begin{tabular}{|c|c|c|c|c|c|c|c|c|c|c|}
\hline Transakcja & 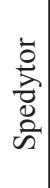 & 点 & 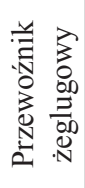 & 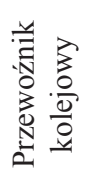 & 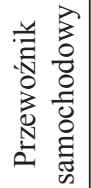 & 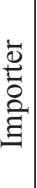 & 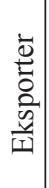 & 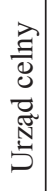 & 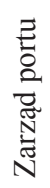 & Platformy \\
\hline 1 & 2 & 3 & 4 & 5 & 6 & 7 & 8 & 9 & 10 & 11 \\
\hline Wypłynięcie statku & $\cdot$ & & - & $\bullet$ & • & & $\bullet$ & & & VIP, EDI \\
\hline Przybycie statku & $\cdot$ & $\cdot$ & & • & - & $\cdot$ & & & $\cdot$ & VIP, EDI \\
\hline Zlecenie transportowe & $\cdot$ & $\cdot$ & • & - & • & & & & & IMP,EMP \\
\hline Deklaracja eksportowa & $\cdot$ & $\cdot$ & $\bullet$ & & & & $\cdot$ & $\cdot$ & & EMP \\
\hline $\begin{array}{l}\text { Zlecenie portowe } \\
\text { eksportowe Hamburg }\end{array}$ & $\cdot$ & $\bullet$ & $\bullet$ & & & & $\cdot$ & & & EMP \\
\hline $\begin{array}{l}\text { Zlecenie portowe } \\
\text { eksportowe Bremer }\end{array}$ & • & • & & & & & & & & EMP \\
\hline Eksport decs Rotterdam & $\cdot$ & $\bullet$ & • & & & & & & & EMP \\
\hline Deklaracja NCTS & $\cdot$ & & • & - & & & $\cdot$ & $\cdot$ & & ZODIAK \\
\hline Deklaracja podsumowania & $\cdot$ & & • & • & & & $\cdot$ & $\cdot$ & & IMP, ZODIAK \\
\hline Deklaracja importowa & $\cdot$ & & • & • & & - & & $\cdot$ & & ZODIAK \\
\hline Powiadomienie importowe & $\cdot$ & $\cdot$ & • & & & $\cdot$ & & $\cdot$ & & IMP, ZODIAK \\
\hline $\begin{array}{l}\text { Przejście przez bramę/zlecenie } \\
\text { zwolnienia }\end{array}$ & $\cdot$ & - & • & & • & & & & & IMP, ZODIAK \\
\hline $\begin{array}{l}\text { Wstępne powiadomienie } \\
\text { samochodu }\end{array}$ & & $\bullet$ & & & • & & & & & EDI \\
\hline Konosament & $\cdot$ & & - & & & & $\cdot$ & & & EMP \\
\hline Dane ładunkowe & $\cdot$ & & $\cdot$ & & & & $\cdot$ & & & EMP \\
\hline $\begin{array}{l}\text { Booking/potwierdzenie } \\
\text { bookingu }\end{array}$ & • & & • & & & & • & & & UNIBOOK \\
\hline Dane manifestu & & & • & & & & & $\cdot$ & & EMP \\
\hline Kody & $\cdot$ & $\cdot$ & - & • & • & $\cdot$ & $\cdot$ & & $\cdot$ & DAKOSY \\
\hline Raport wejścia przez bramę & $\cdot$ & • & • & & & & & & & EMP,IMP \\
\hline Raport wyjścia przez bramę & $\cdot$ & $\cdot$ & • & & & & & $\cdot$ & & EMP, IMP \\
\hline Raport załadunku/wyładunku & $\cdot$ & $\cdot$ & • & & & & & & & EMP \\
\hline
\end{tabular}




\begin{tabular}{|c|c|c|c|c|c|c|c|c|c|c|}
\hline 1 & 2 & 3 & 4 & 5 & 6 & 7 & 8 & 9 & 10 & 11 \\
\hline Raport uszkodzenia/naprawy & & - & $\bullet$ & & & & & & & EDI \\
\hline $\begin{array}{l}\text { Deklaracja ładunku } \\
\text { niebezpiecznego }\end{array}$ & & • & $\bullet$ & • & & & & & • & GEGIS \\
\hline $\begin{array}{l}\text { Plan sztauowania/ } \\
\text { plan rzędu kontenerów }\end{array}$ & & - & • & & & & & & & EDI \\
\hline Faktura & - & - & • & & & & & & & EDI \\
\hline $\begin{array}{l}\text { Ogólnodostępne dane } \\
\text { formatowane }\end{array}$ & • & - & • & • & • & • & • & & • & All \\
\hline Status wiadomości & $\cdot$ & - & $\bullet$ & $\bullet$ & • & - & • & $\bullet$ & $\cdot$ & All \\
\hline Dane statystyczne & $\cdot$ & - & $\bullet$ & & & & & & & EDI \\
\hline Zlecenie załadunku na kolej & - & - & • & & & & & & & HABIS \\
\hline Status zlecenia na kolej & - & • & • & & • & & & & & HABIS \\
\hline Deklaracja celna kolej & $\cdot$ & - & & $\cdot$ & & & & $\cdot$ & & HABIS \\
\hline Sekwencja wagonu kolejowego & & & & - & & & & & $\cdot$ & HABIS \\
\hline
\end{tabular}

Źródło: opracowanie własne na podstawie [University of Naples 2011, s. 44].

Wyróżnione w tab. 3 dane, informacje i dokumenty dostępne dla użytkowników systemu (spedytorów, operatorów terminali, przewoźników żeglugowych, przewoźników kolejowych, przewoźników samochodowych, importerów, eksporterów, urzędów celnych i zarządów portów morskich) umożliwiają podjęcie różnych działań w zakresie podniesienia sprawności i efektywności łańcuchów logistycznych przechodzących przez porty morskie. Niektóre PCS bardzo silnie zintegrowały nie tylko podmioty uczestniczące bezpośrednio w obrocie portowo-morskim, ale również podmioty pośrednio działające na zapleczu portowym - głównie ogniwa łańcucha transportu lądowego (połączenia port morski-transport intermodalny-terminal lądowy-transport samochodowy oraz port morski-transport samochodowy). Nieliczne PCS obejmują rozwiązania umożliwiające wykorzystanie transportu żeglugi śródlądowej jako transportu komplementarnego dla transportu intermodalnego. Tworzenie krajowego port community system powinno na etapie jego inicjacji uwzględnić możliwość wykorzystania tej przyjaznej środowisku naturalnemu gałęzi transportu.

\section{Wnioski}

Zaprezentowane rozwiązania tworzenia platformy informacyjnej stanowią propozycję do rozważenia, która ma na celu usprawnienie zarządzania współpracą między różnymi ogniwami łańcuchów logistycznych przechodzących przez polskie porty morskie. Warto zwrócić uwagę, że funkcjonalność port community system wpływa na usprawnienie szerokiego zakresu zadań związanych z przygotowaniem przewozu, monitorowaniem ładunków - w szczególności ładunków niebezpiecznych, rozliczeniem finansowym użytkowników platformy itp. Port community system uwzględnia 
potrzeby informacyjne i wspomaga działalność importerów, eksporterów oraz instytucji publicznych. Platforma ta może zostać potraktowana jako instrument wspomagający integrację współpracy różnych użytkowników w zakresie przemieszczania ładunków w łańcuchach logistycznych.

Niewątpliwie stworzenie port community system w polskiej przestrzeni gospodarki morskiej stanowi olbrzymie wyzwanie dla jego realizatorów. Po pierwsze musi zostać określona jego forma prawno-organizacyjna, a więc czy ma to być podmiot prywatny, publiczno-prywatny, czy też publiczny. Po drugie muszą być stworzone przepisy prawne umożliwiające funkcjonowanie takiego systemu w polskiej przestrzeni gospodarczej. Po trzecie trzeba określić grupy danych, informacji i dokumentów, jakie powinny stanowić element transferu między uczestnikami. Po czwarte należy zapewnić bezpieczeństwo i ochronę transakcjom przechodzącym przez ten system. Po piąte należy stworzyć powiązania systemów już stworzonych przez administrację państwową single window (m.in. porty 24 itp.) z systemem PCS. Po szóste należy stworzyć rozwiązania zapewniające bezpieczną transmisję danych przez prywatne przedsiębiorstwa, co może powodować poważne bariery uniemożliwiające efektywne implementowanie PCS.

\section{Literatura}

9 SKEMA, 2007, 7th FP project SST-2007-TREN-1-SST.2007.

EPCSA (20.04.2016).

Ficoń K., 2013, Logistyka morska - statki, porty, spedycja, Bel Studio, Gdynia.

Grizell P., 2001, The Economic Potentials for a Port Community System in the Ports of the Netherlands. Master thesis, Erasmus University Rotterdam.

Keceli Y., 2011, A proposed innovation strategy for Turkish port administration policy via information technology, Maritime Policy \& Management, no. 38(2).

Klopott M., Miklińska J., 2016, E-customs and Importers' Port of Choice-Experiences from Poland, Proceedings of the $16^{\text {th }}$ European Conference on e-Government ECEG.

Marek R., 2013, Koncepcja logistyki morskiej w kontekście konteneryzacji, Studia i Materiały Instytutu Transportu i Handlu Morskiego, Gdańsk.

PORTEL, 2016, Inventory of Port Single Windows and Port Community Systems, Sustainable Knowledge Platform for the European Maritime and Logistics Industry. http://www.eskema.eu/DownloadFile.asp ?tableName=tblSubjectArticles\&field=PDF\%20F ilename\&idField=subjectArticleID\&id=231 (25.02.2016).

PORTEL, Inventory of Port Single Windows and Port Community Systems. Released within the 7th FP project SKEMA: Sustainable Knowledge Platform for the European Maritime and Logistics Industry.

Rodon J., Ramis-Pujol J., 2006, Exploring the Intricacies of Integrating with a Port Community System, BLED 2006, Proceedings.

University of Naples, 2011, University of Naples Collaboration of RAM, MED - PCS "Promotion Port Community System" in Mediterranean Traffic, D411 - General study "Implementation of the PCS in Europe".

[www1] http://www.globeinst.org/research/port-community-systems

[www2] http://www.epcsa.eu/about/members/founding-members/soget (8.03.2017).

[www3] http://www.epcsa.eu/downloads-links/epcsa-documents/white-papers-and-consultations. 